\title{
Nitrogen fertiliser use on Swiss grassland
}

\author{
P. THOMET ${ }^{1}$ and J. PITT ${ }^{2}$ \\ ${ }^{1}$ Swiss College of Agriculture, CH 3052 Zollikofen \\ ${ }^{2}$ Agricultural Institute of Grangeneuve, CH 1725 Posieux
}

\begin{abstract}
Nitrogen $(\mathrm{N})$ fertilisation plays an important role in Swiss grasslands, not only as a production factor but also as an ecological criterion determining direct payments for farmers. $\mathrm{N}$ fertiliser use reflects this duality and the grassland-based milk production is influenced by the sustainable type of approach. For comparable milk yields per cow, 4-6 times less concentrate feed is used and 7-9 times less artificial $\mathrm{N}$ is applied per ha of forage land than in the main milk producing regions of Western Europe. Grassland fertilisation is based primarily on farm-produced slurry, which is carefully stored and spread on grassland. Consequently, the average $\mathrm{N}$ balance surplus (= risk for pollution) on intensive Swiss dairy farms is as low as $109 \mathrm{~kg} \mathrm{~N} / \mathrm{ha} /$ year compared to over $400 \mathrm{~kg}$ in high input areas like The Netherlands. In good grass production regions in the Swiss lowlands, $20 \mathrm{~kg}$ DM could be gained per $\mathrm{kg}$ additional $\mathrm{N}$. However, the permitted level of $\mathrm{N}$ use is low in Switzerland. In addition to the slurry N, only $25-50 \mathrm{~kg}$ artificial N/ha/year can be applied to grassland. The Swiss farmers receive high direct payments (about \$NZ1000/ha) from the state for applying a strictly environmentally friendly farming system.
\end{abstract}

Keywords: dairy farming, environment, grassland, nitrogen budget, nitrogen fertilisation, sustainable agriculture

\section{Introduction}

Swiss farmers operate under one of the most highly subsidised and regulated agricultural systems in the world, where nitrogen $(\mathrm{N})$ fertilisation plays a key role not only as a production factor but also as an ecological criterion determining eligibility for government payments. The question as to what level of $\mathrm{N}$ fertilisation is "ecological" in grasslands has become extremely important in Switzerland, where policy directives sometimes tend to be at variance with available scientific evidence. It is important therefore to compare ecological balance sheets internationally to evaluate the validity of the Swiss performances.
The general plan of this paper is to describe first the basic parameters of Swiss grasslands and their use, the agro-political situation prevalent in determining $\mathrm{N}$ use, be it organic or synthetic, and lastly the development prospects of the Swiss grasslands as an ecologically sustainable system.

The question still has to be asked whether the Swiss system is optimal and whether the export orientation of grassland and consequent $\mathrm{N}$ use provides a comparative model of ecological efficiency as opposed to an economic profit model.

The Swiss dairy farming is not directed unilaterally towards profit maximisation, but takes into consideration the concerns of the majority of the population regarding the quality of the landscape and the environment (Noesberger 1993).

\section{The parameters of Swiss grassland production}

Switzerland is a small alpine country with extremely variable local conditions. The climate, topography and soils of many regions are not adapted to cropping. Grassland accounts for $72 \%$ of the agricultural land which is principally used for milk and beef production. Because of the altitude and continental climate, the zero growth period for grass extends from November to the end of March. This requires a significant quantity of conserved forage (60\% hay, $40 \%$ silage). Roughly half of Swiss milk is transformed into raw milk cheese (from non-silage-fed cows) and cheese exports represent $25 \%$ of the milk volume. Raw milk cheeses are made in village type cheese factories (2500 cheese makers throughout Switzerland). Farmers are strictly bound by milk quotas.

Mown and grazed permanent grassland, which represents a majority of the agricultural land, has the following botanical composition: 50-70\% grasses, 15$20 \%$ legumes, $15-30 \%$ other species. Approximately $12 \%$ of grasslands are leys on the mixed (cropping + dairying) lowland farms. The leys are always a mixture of grasses and legumes and are generally used for 2-3 seasons.

Relatively high milk yields can be obtained from these grasslands. In the lowlands, $70-90 \%$ of the average $418 \mathrm{~kg} \mathrm{MS} / \mathrm{cow}$ is produced from roughage (grass and 
hay). The milksolids (MS) yield per ha of grassland is 576-720 kg MS/year (including all heifers on the farm) in the intensive dairy regions.

\section{The relationship between agricultural policy and $\mathbf{N}$ use on grassland}

Swiss agricultural policy is based on the recognition that agriculture fulfils more than the traditional function of producing food. The so-called multifunctions of agriculture in Swiss society can be summarised in Table 1.

Table 1 The multifunctions of agriculture in an advanced society (Popp 1994)

1. Production of goods for market (including food security)

2. Services to society with no market price (public goods)

2.1. Maintenance of landscape (gardener of nature, asset for tourism and recreation)

2.2. Decentralized settlement to combat negative aspects of urbanisation

2.3. Cultural heritage and social values

2.4. Long run sustainability of the ecological system (soil, water, air, biodiversity)

This broader conception of two categories of services produced by agriculture, and in particular grassland farming, calls for different methods of farmer remuneration (not only income through produce sales) in order to guarantee the delivery of the so-called public goods. The government programme applied since 1993 consists of decoupling subsidies and farm produce. In other words, farmers receive lower market prices for farm products and direct payments independently of production volumes, according to the "greenbox" principle mentioned in the WTO agreement. However, the direct payments are available only to farmers who meet numerous ecological criteria, of which limited $\mathrm{N}$ use is one.

Every one of these farmers has to calculate and to present a nutrient budget (Table 2). The $\mathrm{N}$ and phosphorus budget has to be well balanced (= not more than $10 \mathrm{~kg}$ surplus per ha). Slurry is the primary $\mathrm{N}$ source on grasslands. Only about $20-40 \mathrm{~kg} / \mathrm{ha} /$ year of synthetic $\mathrm{N}$ can be used.

Farmers have to build effluent storage units for 3-6 months storage capacity in water-tight concrete or metal containers (\$NZ1500 per cow). Research and extension work is striving to find ways of reducing $\mathrm{N}$ losses through better slurry management.

In $1997,70 \%$ (projection $90 \%$ for year 2000) of the agricultural land was farmed according to the "ecological farming system". The very high direct
Table 2 Swiss method used for the establishment of an annual $\mathrm{N}$ budget for grassland as applied in integrated farming programme (per ha)

Stocking rate used for this example: $1.6 \mathrm{LU} / \mathrm{ha}$ (LU=livestock unit $=600$ $\mathrm{kg}(W)$

1. Estimation of the DM production of the grassland based on the stocking rate and the DM intake of the cattle units $1.6 \times 6 \mathrm{t} \mathrm{DM} / \mathrm{ha}=$ 9.6 t DM

2. Nitrogen needs per ha for intensive swards: $12 \mathrm{~kg} \mathrm{~N} / \mathrm{t} \mathrm{DM} \times 9.6 \mathrm{t} \mathrm{DM}=$ $115 \mathrm{~kg} \mathrm{~N}$ We accept that other needs will be covered by legume fixation, mineralisation and deposition

3. Estimation of the $\% \mathrm{~N}$ efficiency in liquid manure (slurry) according to standard values: $\mathrm{N}$ production of a cow with $6000 \mathrm{~kg}$ milk/year $=115 \mathrm{~kg} \mathrm{~N}_{\text {tot }}$ year, minus 15\% losses during storage $=98 \mathrm{~kg} \mathrm{~N}^{1}$, of which $60 \%$ efficiency $=59 \mathrm{~kg} \mathrm{~N}$ available $/$ cow $1.6 \mathrm{LU} / \mathrm{ha} \times 59 \mathrm{~kg} \mathrm{~N} / \mathrm{av} / \mathrm{cow}=$ $94 \mathrm{~kg} \mathrm{~N}$ av(slurry)

4. Amount of purchased $\mathrm{N}$ (artifical) permitted $115 \mathrm{~kg} \mathrm{~N}$ needs $-94 \mathrm{~kg}$ slurry $\mathrm{N}_{\mathrm{av}}=\quad 21 \mathrm{~kg} \mathrm{~N}_{\text {artificial }}$

$\mathrm{N}$ of excreta returned during grazing is accounted only $50 \%$

payments (about \$NZ1000 per ha) encourage most farmers to participate.

In conclusion, Swiss farmers are forced by dropping market prices to obtain eligibility for direct payments, thereby meeting the ecological criteria. In relation to nitrogen use this implies that it is no longer maximum profit that dictates fertilisation levels but a balanced nutrient budget.

\section{Swiss grasslands as an ecological model}

Switzerland $\mathrm{N}$ use and milk production on grassland appears much more balanced than in other European countries. A comparison between Europe's most important dairy regions shows that roughly five times less concentrate feed per cow and seven times less artificial $\mathrm{N}$ per ha is used in Switzerland (Table 3). One could say that milk is produced essentially from "on-farm" grown resources in Switzerland. Because of high concentrate prices (compared to milk price), not only ecological arguments but also economic reasons explain the high proportion of milk produced from the grassland.

The $\mathrm{N}$ balances of 19 typical dairy farms in the region of Luzern with an intensive grassland management were compared with those of Dutch dairy farms (Table 4). On average the Swiss dairy farmers used only $343 \mathrm{~kg}$ of concentrates per cow and $27 \mathrm{~kg} \mathrm{~N} / \mathrm{ha} /$ 
Table 3 Comparison of nitrogen fertiliser and concentrate use in dairy farming of several European countries (1994)

\begin{tabular}{ccc}
\hline $\begin{array}{c}\text { Artificial N fertiliser } \\
\mathrm{kg} / \mathrm{ha} / \text { year }\end{array}$ & $\begin{array}{c}\text { Concentrates } \\
\mathrm{kg} / \text { cow/year }\end{array}$ & $\begin{array}{c}\text { Stocking rate } \\
\text { cows/ha }\end{array}$ \\
\hline
\end{tabular}

\begin{tabular}{|c|c|c|c|}
\hline \multicolumn{4}{|l|}{ Switzerland } \\
\hline - central part ${ }^{1}$ & 27 & 343 & 1.6 \\
\hline - eastern part ${ }^{2}$ & 36 & 213 & 1.4 \\
\hline
\end{tabular}

\begin{tabular}{lccc}
\hline Europe $^{3}$ & & & \\
The Netherlands & 331 & 2100 & 2.7 \\
Germany-North & 180 & 1800 & 1.8 \\
France-West & 220 & 1100 & 2.2 \\
Italy (valley of Po) & $?$ & 3100 & 2.7 \\
Great Britain & 230 & 2000 & 2.3 \\
Ireland & 265 & 670 & 2.7 \\
\hline
\end{tabular}

average of 10 typical dairy farms (1992-94)

2 average of 4 typical dairy farms (1993-95)

3 Pflimlin (1995)

year of mineral $\mathrm{N}$ fertiliser. Consequently, the average nitrogen surplus on the Swiss farms was as low as 109 $\mathrm{kg} \mathrm{N} / \mathrm{ha} /$ year compared to $486 \mathrm{~kg}$ on the Dutch farms. Several reasons for these differences were identified: (1) The fertiliser recommendations for intensive grassland in the two countries are quite different; (2) The Dutch farms import large quantities of nitrogen through their extensive use of purchased feed (concentrates); (3) Legumes are an important component of Swiss permanent grassland and leys; more than $40 \%$ of the total $\mathrm{N}$ input on the Luzern dairy farms were estimated to come from biological $\mathrm{N}$ fixation $(59 \mathrm{~kg} \mathrm{~N}$ ha/year; Boller \& Noesberger 1987). The farms with dairy and pig production are in a more comfortable situation. They have an extra $84 \mathrm{~kg} \mathrm{~N} / \mathrm{ha} /$ year via purchased pig feed, which allows a $17 \%$ higher milk production per ha.

\section{What level of $\mathbf{N}$ fertilisation is sustainable?}

It has been shown in Table 5 that the actual levels of $\mathrm{N}$ fertilisation permitted under the "ecological farming" programme are extremely low in comparison to those of other countries. It is therefore interesting to analyse the effects and responses of $\mathrm{N}$ fertilisation. The comparison of farms with different $\mathrm{N}$ levels for more than 15 years shows that $\mathrm{N}$ has a very pronounced influence on the productivity per ha (Jacob 1991; Thomet \& Wolf 1996). $\mathrm{N}$ fertilisation levels ranging from $150 \mathrm{~kg}$ to $340 \mathrm{~kg}$ $\mathrm{N}_{\text {tot }} /$ ha/year result in a DM yield from 10 to $14 \mathrm{t} / \mathrm{ha} \mathrm{DM}$, giving a response of $21-22 \mathrm{~kg} \mathrm{DM} / \mathrm{kg} \mathrm{N}$. The primary effect measured in trials is lower (about $12-16 \mathrm{~kg} \mathrm{DM}$ ) but more DM allows a higher stocking rate. The amount
Table 4 Annual $N$ balances of specialised dairy farms in Switzerland (intensive grassland region Luzern) and in The Netherlands

\begin{tabular}{|c|c|c|c|}
\hline $\mathrm{kg} \mathrm{N} / \mathrm{ha} /$ year & $\begin{array}{c}\text { Swiss farms }{ }^{1} \\
\text { dairying only } \\
1992-94\end{array}$ & $\begin{array}{c}\text { Swiss farms } \\
\text { dairying + pigs } \\
\text { 1993-95 }\end{array}$ & $\begin{array}{c}\text { The } \\
\text { Netherlands } \\
1983-86 \\
\end{array}$ \\
\hline number of farms & 10 & 9 & 175 \\
\hline stocking rate (cows/ha) & 1.6 & 1.9 & 2.7 \\
\hline \multicolumn{4}{|l|}{ Inputs } \\
\hline purchased roughage & 4 & 3 & 44 \\
\hline purchased concentrates & 14 & 132 & 137 \\
\hline artificial fertilisers & 27 & 20 & 331 \\
\hline slurry from other farms & 16 & 0 & 0 \\
\hline atmospheric deposition & 28 & 28 & 48 \\
\hline biological $\mathrm{N}$-fixation & 59 & 50 & \\
\hline miscellaneous & 4 & 3 & 8 \\
\hline Total & 152 & 236 & 568 \\
\hline \multicolumn{4}{|l|}{ Outputs } \\
\hline milk & 32 & 37 & 67 \\
\hline sold livestock & 11 & 38 & 14 \\
\hline sold roughage & 0 & 6 & 1 \\
\hline Total & 43 & 81 & 82 \\
\hline Surplus & 109 & 155 & 486 \\
\hline $\begin{array}{ll}1 & \text { Thomet \& Koller (1996 } \\
2 & \text { Aarts et al. (1992) }\end{array}$ & & & \\
\hline
\end{tabular}

Table 5 A comparison of $\mathrm{N}$ fertiliser recommendations ( $\mathrm{kg}$ $\mathrm{N} / \mathrm{ha}$ ) for cut and for grazed swards in Switzerland and England/Wales

\begin{tabular}{lcc}
\hline & Grazing & Cutting \\
\hline Switzerland & & \\
Integrated system with direct payments; & & \\
example 1.6 cows/ha & & \\
net yield (eaten t DM/ha/year) & 8.4 & 10.0 \\
$N$ recommendations per rotation or cut & 20 & 30 \\
$N$ recommendations per year & 65 & 120 \\
\hline slurry N total & 30 & 157 \\
slurry N available $\left(60 \%\right.$ of $\mathrm{N}_{\text {tot }}$ ) & 18 & 94 \\
artificial N fertiliser (purchased) & 47 & 26 \\
\hline
\end{tabular}

\section{England/Wales'}

recommendations per year

$300-380 \quad 340-420$

${ }^{1}$ Unwin \& Vellinga (1994)

of slurry and organic $\mathrm{N}$ is increased owing to $\mathrm{N}$ recycling. Both effects together explain the good response of over $20 \mathrm{~kg} \mathrm{DM} / \mathrm{kg} \mathrm{N}$ applied.

The results of all trials and farm analyses on the Swiss plainlands show a good potential for increased productivity with a high $\mathrm{N}$ fertilisation level. Yields of over $15 \mathrm{t} \mathrm{DM} / \mathrm{ha} /$ year are possible. 
From an economic point of view, $\mathrm{N}$ fertilisation levels of around $300 \mathrm{~kg} / \mathrm{ha} /$ year could be recommended. The official limits permit only half of this quantity. A lot of research has been done in Europe in the last few years as to what level of $\mathrm{N}$ fertilisation is sustainable. The main concern has been to reduce nitrate content in drinking water. However, nitrate leaching increases sharply when an intensive pasture is fertilised with more than $150-200 \mathrm{~kg} \mathrm{~N} / \mathrm{ha} /$ year and a meadow with more than $350 \mathrm{~kg} / \mathrm{ha} /$ year (Whitehead 1995). This suggests that Swiss grassland farms could increase their productivity without approaching $\mathrm{N}$ fertilisation levels that endanger natural resources.

\section{Outlook}

It would appear that agricultural policy of decoupled payments for a multifunctional farming system has maintained a low level of $\mathrm{N}$ use on Swiss grasslands in comparison with $\mathrm{N}$ fertiliser use in other milk producing regions of Europe. This contributes to making Swiss milk production more ecologically sustainable but unfortunately more expensive and therefore less competitive. A moderate lift of the actual low fertiliser limit would not lead to levels endangering natural resources, but would reinforce economic viability of the small family farm structures.

But is ecological sustainability really so important for the competitive farming nations? In all industrialised countries the farming communities represent a minority of the population. This means that no matter how profitable a non-ecological farming system may be, it will probably not be tolerated in the long run by the rest of the population. Despite the need for some minor adjustments, Swiss farmers have had to meet the challenge of finding a system compatible with the expectations of the non-agricultural population. In this sense we feel that the Swiss grassland system does represent a pioneer model for other countries, where striving for long-term sustainability, be it social or environmental, remains in the centre of the agricultural system.

\section{REFERENCES}

Aarts, H.F.M.; Biewinga, E. E.; van Keulen, H. 1992. Dairy farming systems based on efficient nutrient management. Netherlands journal of agricultural science 40: 285-299.

Boller, B.; Noesberger, J. 1987. Symbiotically fixed nitrogen from field-grown white and red clover mixed with ryegrasses at low levels of ${ }^{15} \mathrm{~N}$ fertilization. Plant and soil 104: 219-226.

Jacob, H. 1991. Stickstoffeinsatz und Stickstoffeffizienz in baeuerlichen Gruenlandbetrieben des Wuertembergischen Allgaeus - Ergebnisse aus Betriebsanalysen. Das Wirtschaftseigene Futter 37: 169-185.

Noesberger, J. 1993. The Swiss Grassland System. pp. 95-103. In: Haggar R.J.; Peel S. (eds.). Grassland Management and Nature Conservation. Occasional Symposium No. 28, British Grassland Society.

Pflimlin, A. 1995. Europe laitière: diversité, spécifités et complémentaires. Fourrages 143: 5-20.

Popp, H.W. 1994. Socio-economic aspects of forage production, rural development and surpluses of animal products. Proceedings of the 15th General Meeting of the European Grassland Federation, Wageningen, The Netherlands: 477-484.

Thomet, P.; Koller, P. 1996. Gute N-Effizienz auf Luzerner Milchwirtschaftsbetrieben [Nitrogen balances of Swiss dairy farms]. Agrarforschung 3: 77-80.

Thomet, P.; Wolf, S. 1996. N-Düngung und wettbewerbsfaehige Milchproduktion. Die Gruene 45: 21-23.

Unwin, R.J.; Vellinga T.A. 1994. Fertilizer recommendations for intensively managed grassland. Proceedings of the 15th General Meeting of the European Grassland Federation, Wageningen, The Netherlands: 590-602.

Whitehead, D.C. 1995. Grassland Nitrogen. Wallingford, UK, CAB International, pp. 129-140. 